\title{
O discurso jurídico metafórico e a construção retórica de verdades no direito
}

The metaphorical legal speech and the rhetorical construction of truth in law

\author{
Pedro Parini
}

\section{RESUMO}

No presente ensaio defendo que o estabelecimento de um modelo adequado de compreensão do direito depende do desenvolvimento de uma epistemologia da metáfora. Minha hipótese é de que a produção de conhecimento jurídico estaria intrinsecamente ligada à capacidade tipicamente humana de lidar com os aspectos figurativos da linguagem do direito. Desse modo, o conceito de verdade no direito dependeria da noção de verdade metafórica para a qual a ideia de correspondência entre linguagem e realidade, assim como a ideia de consenso são irrelevantes do ponto de vista retórico. Para defender esta tese, parto do pressuposto de que a própria ideia de sentido literal é em si metafórica e serve apenas como referencial para o desenvolvimento de interpretações não literais dos textos normativos. Dessa forma, concluo afirmando que a semântica do direito depende sempre de sua pragmática, isto é, que a produção de sentido jurídico está atrelada a questões de performance e uso criativo da linguagem.

Palavras-chave: Retórica. Direito. Metáfora. Epistemologia.

\begin{abstract}
In this essay I argue that the establishment of a proper model for the understanding of law depends on the development of an epistemology of metaphor. My hypothesis is that the production of knowledge would be intrinsecally conected to the typical human faculty of dealing with figurative aspects of legal language. Thereby the concept of truth in the legal domain would depend on the concept of metaphorical truth for which the idea of correspondence between language and reality, as well as the idea of consensus are irrelevant from a rhetorical point of view. To advocate this thesis I assume that the very idea of literal meaning is metaphorical and that it functions only as a referential to the development of non-literal interpreta-
\end{abstract}


tions of normative texts. Thus, I conclude affirming that legal semantics depends on its pragmatics, i.e., that the production of legal meaning is connected to performative issues and creative use of language.

Keywords: Rhetoric. Law. Metaphor. Epistemology.

O discurso tem um poder próprio e específico, que é o seu significado.

(CASERTANO, 2010, p. 26)

\section{Introdução}

O presente ensaio tem como objetivo a discussão sobre a pertinência de uma epistemologia própria da metáfora que sirva à compreensão do direito. Aqui, defendo as hipóteses de que a linguagem metafórica propicia uma forma particular de conhecimento e de que a produção de conhecimento jurídico depende diretamente do potencial criativo de sua linguagem metafórica.

Além disso, procuro apontar como a noção de sentido literal é tomada por óbvia nos discursos teóricos, mesmo quando os juristas não conseguem expurgar o caráter figurativo da linguagem que empregam para se referir aos fenômenos jurídicos.

As teorias dogmáticas do direito tendem a encarar a tese da literalidade da interpretação dos textos normativos como algo óbvio tanto para enaltecê-la enquanto ideal hermenêutico, quanto para rechaçá-la como sendo algo impossível de se realizar. Em alguns casos, quando há sensibilidade retórica por parte das teorias, a interpretação literal assume apenas um caráter operacional e performático livre de qualquer ontologia. Nestes casos, a economia da noção de literalidade do discurso jurídico se limita à satisfação de um auditório determinado em um contexto particular.

Por fim, defendo que é a competência para manipular a linguagem figurada do direito e seus sentidos metafóricos que permite a evolução científica da jurisprudência e a adequação das várias dogmáticas às diferentes realidades que se manifestam no tempo e no espaço. 


\section{A linguagem jurídica dogmática e o sentido literal no lugar do metafórico}

Ironicamente, nós os juristas, práticos ou teóricos, referimo-nos constantemente à literalidade quando acerca dela temos pouca ou quase nenhuma certeza. John Searle (1993, p. 85), por outro lado, critica os autores que se propõem a investigar a metáfora quando simplesmente tomam por certo e não problemático o significado da noção de sentido literal.

A determinação do que represente o sentido literal, contudo, nada tem de óbvio. Segundo pesquisas no campo da psicologia cognitiva, por exemplo, a própria questão da maneira como é normalmente formulada não se coloca nem mesmo como pertinente, pois não haveria uma diferença essencial ou ontológica entre a compreensão de um discurso literal e de outro metafórico (RUMELHART, 1993, p. 72). A própria ideia de literalidade talvez só tivesse sentido se a afirmação da noção de metaforicidade fosse posta como objetivo. Mas isso não quer dizer que a implicação se dê em apenas um sentido.

Quando se destaca a noção de metaforicidade, ressalta-se diretamente, mesmo que sem querer, a noção de literalidade, da mesma forma que, por contraste, a cor branca reforça a preta e vice-versa, ou a ideia do bem reforça a do mal, assim como tudo aquilo que é considerado em uma relação de oposição. Afirmar a importância da metáfora na constituição da linguagem e do pensamento humanos equivaleria assim ao mesmo tempo a destacar a noção de literalidade, pois só há metáfora na medida em que há também o sentido literal que a metáfora, em tese, viola. Essa é uma maneira inexoravelmente dialética de ver a relação entre sentido literal e sentido metafórico.

Vendo a questão de outro ângulo, a própria ideia de literalidade pode ser entendida como metafórica, diante de sua vinculação à imagem da letra que, ao corresponder a um som, captura e acorrenta também o seu sentido. No entanto, ao declarar como falsa ou apenas aparente a dicotomia entre literal e metafórico, passa a ser plausível falar apenas em metaforicidade e na ausência completa de qualquer sentido literal, ou, ao contrário, em literalidade e na inexistência de sentidos figurados. 
Sobre a noção de literalidade, podemos elencar algumas presunções falsas que predominam no senso comum (LAKOFF, 1993, p. 204).

Em primeiro lugar, a afirmação de que toda linguagem cotidiana convencional é literal. Sabemos que as metáforas estruturam boa parte não só das expressões linguísticas mais ordinárias como também a própria maneira do pensar convencional a respeito de noções elementares à nossa vida cotidiana como as noções de mundo, tempo, mercado, lei, ordenamento etc.

Em segundo lugar, a ideia de que todo assunto pode ser compreendido literalmente sem o recurso a expressões metafóricas. Isso equivaleria a dizer que as metáforas são, na nossa linguagem conceitual, supérfluas, acessórias ou mesmo dispensáveis. Contra essa ideia, pode-se dizer também que sem metáfora, em vários domínios, dificilmente seríamos capazes de falar ou sequer pensar. E, em terceiro lugar, a presunção de que toda definição léxica é literal e não metafórica quando se sabe que com a definição do conceito de direito, por exemplo, seria exatamente o contrário: sem as noções metafóricas não teríamos como definir e, portanto, racionalizar a experiência jurídica e os fenômenos que consideramos jurídicos (PARINI, 2014a).

Na verdade, é um sistema de metáforas que estrutura parte significativa de nosso sistema conceitual ordinário, inclusive no que diz respeito aos conceitos mais abstratos. A modificação do próprio conceito de metáfora com as teorias contemporâneas diluiu a dicotomia antes forte entre literalidade e metaforicidade.

0 grande problema para a teoria da metáfora, no entanto, é manter a noção de metaforicidade sem recorrer à oposição entre sentido literal e sentido metafórico. Se tudo é metafórico, é porque nada é literal. Mas sem literalidade não haveria metaforicidade.

A ampliação do sentido da expressão metáfora no estudo contemporâneo pode criar um sério problema para o seu estudioso: o conceito de metáfora termina por cobrir uma série de noções, como se qualquer expressão linguística fosse inexoravelmente metafórica, fazendo com que a própria noção de metáfora se tornasse vã ou trivial. 
Metáfora tem sido até agora definida de modos tão diferentes que não há nenhuma expressão humana, seja na linguagem ou em outro meio, que não seja metafórica na definição de alguém. Isso poderia significar que a palavra se tornou inútil e que deveríamos assumir outra linha de investigação. Certamente quando uma palavra pode significar todas as coisas ela corre o risco de significar nada. Mas o que há de interessante é que, a despeito das diferenças relativas ao escopo de nossas definições, todos nós encontramos, a cada dia, certos enunciados que todos reconhecem como metáfora e o chamam por esse nome ${ }^{1}$ (BOOTH, 1979, p. 48).

O aumento exponencial nos últimos tempos do interesse nos estudos da linguagem metafórica e a enorme variedade de teorias que fazem com que vejamos figuratividade em tudo pode simplesmente banalizar a própria ideia de metáfora.

As teorias contemporâneas, portanto, tendem a hipertrofiar o sentido do conceito de metáfora considerando que a velha distinção entre literal e metafórico sempre foi baseada em pressuposições falsas. 0 sentido contemporâneo de literalidade estaria associado ao maior grau de aproximação que as expressões têm em relação ao mundo empírico ou às experiências do mundo físico. À medida que os discursos começam a se afastar dessa experiência do concreto e chegam a falar de abstrações ou emoções, a literalidade passa a dar lugar à compreensão metafórica. A velha distinção literal-metafórico, portanto, como uma oposição entre o sentido próprio e o sentido deslocado é substituída por outra ideia (LAKOFF, 1993, p. 205). 0 problema é que as teorias contemporâneas não parecem deixar muito claro o que seria essa nova concepção da relação entre o sentido literal e o metafórico. Mais uma vez ela parece simplesmente ser assumida como válida, talvez para permitir que se fale ainda em linguagem figurada com alguma pertinência.

Deixando de lado temporariamente esse problema de ordem filosófica ou epistemológica, pensemos no binômio literal-metafórico como uma estratégia retórica não só da linguagem teórica, mas também da linguagem dogmática da retórica prática dos juristas.

$\mathrm{Na}$ origem do desenvolvimento do pensamento jurídico moderno, estava fortemente presente a ideia de literalidade das expressões que 
constituem a linguagem jurídico-dogmática, de maneira a permitir um maior grau de confiança na lei e no direito escrito.

O que fundamentaria a quantidade absurda de documentos que se produzem para certificar o direito na Modernidade? Provavelmente a ideia de que escrever o direito, isto é, literalizá-lo ou, propriamente, transformá-lo em letra, seria um modo de torná-lo mais sofisticado ou refinado do ponto de vista de sua racionalidade ou inteligibilidade.

A passagem de um direito não-escrito para um direito escrito, como a passagem de um direito consuetudinário para um direito legislado está relacionada, dentre outros fatores, à necessidade de se formular linguisticamente com maior precisão o conteúdo desse direito. Aquilo a que se refere o direito, isto é, sua semântica, parece depender sobremaneira, na Modernidade, de suas fórmulas escritas. Claramente essa não é uma característica exclusiva da Modernidade. Esteve também presente na passagem de um direito consuetudinário não-escrito para um direito consuetudinário escrito, como no exemplo mor da Lei das XII Tábuas. 0 aumento da complexidade e da contingência das relações econômicas e sociais faz com que surja a necessidade de maior precisão das formulações linguísticas, de forma a evitar a dispersão das possíveis interpretações que, em uma sociedade iletrada, depende da convergência ideológica de seus membros e de interpretações preponderantemente intuitivas.

Com a escritura do direito e a preponderância dessa sobre outras formas de constituí-lo e expressá-lo, surge consequentemente o apego à literalidade que, por sua vez, pode ser entendido como adoração da letra, isto é, da escrita. Como se o direito, para ser produzido, dependesse da lei. Como se a inteligência do direito dependesse, sobretudo, da correta leitura de seu teor literal.

Faz séculos que a linguagem artificial dos matemáticos fornece, a muitas pessoas de tino, um ideal de clareza e de univocidade que as línguas naturais, menos elaboradas, deveriam empenhar-se em imitar. Nessa perspectiva, consideram-se imperfeições toda ambigüidade, toda obscuridade, toda confusão, elimináveis não só em princípio, mas ainda de fato. A univocidade e a precisão de seus termos fariam da linguagem científica o melhor instrumento para as funções de demonstração e de verificação, e são essas características que se queria impor a toda linguagem (PERELMAN; OLBRECHTS-TYTECA, 2005, p. 147). 
Modernamente, dissociar a noção de direito dos documentos e da linguagem que o constituem parece sem sentido. Parte significativa daquilo que é o direito vigente de uma sociedade moderna se encontra publicada em algum documento. Mas isso não quer dizer que o direito esteja no teor literal dos enunciados que compõem esses documentos. Daí as tentativas teóricas da hermenêutica jurídica contemporânea de distinguir norma de texto normativo enfatizando que não há uma relação de identidade entre norma e texto, ou mesmo entre direito e lei, pois, segundo essas teorias hermenêuticas, "o direito não é idêntico ao texto literal da disposição legal” (MÜLLER, 2009, p. 196). Nem mesmo a interpretação gramatical teria como objeto o texto literal, mas a norma (MÜLLER, 2009, p. 197-198).

Se pode ser levado a sério esse ponto de vista das teorias hermenêuticas contemporâneas do direito, então estamos autorizados a dizer que o apego à literalidade de sua linguagem específica torna a dogmática jurídica um jogo irônico que permite ao jurista continuar pensando o direito e empregando suas fórmulas linguísticas - os textos normativos - como algo que transcende o status de mera ferramenta, instrumento, ponto de partida para solução de conflitos ou mero dado de entrada para a concretização da norma. Pensar o direito literalmente é identificá-lo com a lei, com o código, com o texto da constituição, dos acórdãos, das súmulas, dos contratos etc. Mesmo que se tenha consciência de que o texto não é a norma, ou de que o instrumento contratual não é o contrato e assim por diante, o simples fato de depender da literalidade dos enunciados linguísticos sem poder fundamentá-la filosófica ou epistemologicamente, faz do dogmático uma vítima em potencial de uma espécie de ironia situacional.

O sentido literal, de acordo com o que discutimos acima, não pode ser identificado apressadamente com o sentido ordinário de uma palavra ou expressão, dado que diversas formulações linguísticas de nosso cotidiano, que estruturam grande parte da maneira como pensamos a realidade, são metafóricas ou decorrem do entrecruzamento de diferentes domínios conceituais, como na metáfora "tempo é dinheiro" apresentada acima como exemplo para a teoria de Lakoff e Johnson.

A diferença entre sentido literal e sentido metafórico é muitas vezes identificada também com a noção de consenso ou acordo. Quando há pre- 
valência de acordo difuso em relação ao sentido de uma palavra é como se estivéssemos diante de seu sentido literal. De qualquer forma, mesmo assumindo como válido o critério, o problema da distinção permaneceria em aberto visto que não há qualquer fronteira firme o suficiente capaz de demarcar completamente o sentido literal e diferenciá-lo de todos os demais (ARBIB; HESSE, 2008, p. 15). Os acordos são sempre provisórios, circunstanciais e apenas relativamente estáveis, de forma que não há garantia de sua permanência, tampouco de duração de um sentido literal ou metafórico que seja.

Há uma noção bastante difundida no estudo da metáfora que define os sentidos literais como metáforas mortas. Assim, o literal teria sido algum dia metafórico.

No que se refere, por exemplo, à criação do sentido literal para os conceitos de direito ou de Estado, a morte da metáfora pode ser representada pelo esquecimento que a origem de todo direito e do próprio Estado está na força e na violência.

De acordo com Nietzsche (1988a, p. 769-770),

Qualquer que seja, no indivíduo, a potência do seu instinto de sociabilidade, unicamente com punho de ferro pode o Estado forçar as grandes massas a se fundir, de modo que se produza assim, necessariamente, esta separação química da sociedade que acompanha a sua nova estrutura piramidal. (...) A força dá o primeiro direito e não existe direito que, nos seus fundamentos, não fosse abuso, usurpação e violência² .

Apenas ironicamente é que o direito deixa de ser força violenta e torna-se direito. Enquanto a metáfora do direito não se afasta de sua origem violenta, o conceito de direito a nega, transfigurando-a em coerção por meio da distinção entre a violência legitimada e a não legitimada. Mas só com a ironia é possível perceber que "a força dá o primeiro direito". "A magia do Estado em formação"3 (NIETZSCHE, 1988a, p. 770), do ponto de vista filosófico da retórica, está relacionada ao truque (camuflagem) de encobrir a metáfora terrível da origem do Estado como objetivação do instinto de violência e a sua permanência como instrumento cruel de conquista e manutenção do poder pela força. A metáfora do "punho de ferro que força o processo social” ${ }^{4}$ (NIETZSCHE, 1988a, p. 772) se perde 
num emaranhado de conceitos que procuram explicitar teoricamente a noção de Estado como conceito. Enquanto metáfora, a noção de Estado pode se reportar inclusive a uma situação de pura violência; enquanto conceito jurídico, a violência do Estado se legitima como coercitividade.

Para a perspectiva retórica de Nietzsche, falar em sentidos literais seria simplesmente absurdo, presunçoso e precipitado. Isso porque só há sentido literal quando a origem metafórica de uma expressão é olvidada. Toda linguagem, segundo Nietzsche, teria uma origem metafórica, ou seria o fruto de processos tipicamente metafóricos, metonímicos e imagéticos em geral que não se justificam literalmente a partir de relações racionais de correspondência entre uma coisa e o seu nome. Um conceito é o produto de pelo menos dois diferentes saltos injustificáveis. Em primeiro lugar, quando nos deparamos com uma coisa, um objeto ou um fenômeno, há uma impressão sensível que lhe é relativa. Em segundo lugar, há uma tradução dessa impressão em uma imagem que por sua vez é traduzida em um conceito. Este é um processo duplamente metafórico. Sendo a primeira metáfora a passagem de um estímulo nervoso para uma imagem e a segunda metáfora, a passagem da imagem para determinado som (da palavra). Portanto, de acordo com Nietzsche (1988b, p. 878), uma palavra seria uma imagem de um estímulo nervoso transformado em som.

Em princípio um estímulo nervoso é transferido para uma figura! Primeira metáfora. A figura, por sua vez, é imitada em um som! Segunda metáfora. E a cada vez há um completo sobressalto de uma esfera diretamente para o centro de outra completamente nova e diferente ${ }^{5}$ (NIETZSCHE, 1988b, p. 879).

O surgimento da metáfora é, na verdade, o abandono ou distanciamento em relação ao estímulo nervoso originário. Aquilo que é apresentado como sentido cristalizado ou como imagem fixa é ilusão de verdade. Esse processo metafórico cria uma ilusão de correspondência entre a linguagem e o mundo. É possível afirmar, por conseguinte, que "linguagem original ou literal é meramente uma metáfora ou figura que reprimiu os modos pelos quais produz, mais do que nomes, a estabilidade dos conceitos"6 (COLEBROOK, 2006, p. 98). Pois, 
Todo conceito nasce por igualação do não igual. Assim como é certo que nunca uma folha é inteiramente igual à outra, é certo que o conceito de folha é formado por arbitrário abandono dessas diferenças individuais, por um esquecer-se do que é distintivo, e desperta então a representação, como se na natureza, além das folhas, houvesse algo, que fosse 'folha', uma espécie de folha primordial, segundo a qual todas as folhas fossem tecidas, desenhadas, enquadradas, coloridas, onduladas, pintadas, todavia por mãos desajeitadas, de forma que exemplar algum funcionaria correta e autenticamente como verdadeira imagem da forma primordial ${ }^{7}$ (NIETZSCHE, 1988b, p. 880).

A arraigada crença hermenêutica à maneira dogmática de pensar o direito de que a literalidade dos conceitos e de suas interpretações é o caminho para a eliminação de problemas relacionados a incerteza, dúvida, ambiguidade ou vagueza das expressões linguísticas do direito só pode levar a uma situação paradoxal. 0 compromisso com o desenvolvimento de uma linguagem literalizada do direito ou da dogmática jurídica que teria como objetivo a eliminação de elementos linguísticos inúteis é ao mesmo tempo absurdo e contraditório. Isso porque o desenvolvimento da noção de direito e da própria atividade dogmática - de interpretação, reconhecimento e solução de conflitos - depende de seu caráter figurado e da indeterminação que a linguagem propicia no que se refere à adequação do mundo de eventos (ou dos fatos, do ser) ao mundo de ideias (ou das normas, do dever). Noções, mesmo que precárias e simplesmente tomadas por óbvias, como a de "textura aberta da linguagem" empregada por Hart ou de "relativa indeterminação da linguagem" a que recorre Kelsen parecem fundamentais em suas análises hermenêuticas relativas a esse problema de adequação entre dois mundos ou âmbitos diferentes, o da realidade e o das normas. Mas é preciso ter em mente que

A eliminação da ambiguidade e da linguagem "inútil", ou o comprometimento com um completo literalismo é tanto absurdo quanto contraditório. (...) o desejo de uma linguagem pura e literal, uma linguagem livre de ambiguidade ou figuras, produz um caos de coisas, uma escandalosa e insegura coleção de significantes sem qualquer uso coerente ${ }^{8}$ (COLEBROOK, 2006, p. 85).

É justamente essa contradição entre uma postura literalizante das teses dogmáticas e uma necessidade figurativa da linguagem do direito 
que levam à ironia como forma de compreensão do fenômeno jurídico (PARINI, 2014b). 0 paradoxo que propicia uma situação irônica reside nessa situação contraditória entre projeção e execução, isto é, em assumir uma atitude aparentemente literalizante e agir metaforicamente. $\mathrm{Ou}$ ainda, entre afirmar a literalidade, e oferecer a metáfora.

Se não fosse o caráter metafórico da linguagem jurídica com sua plasticidade e potencialidade para a criação, não haveria possibilidade de desenvolvimento das atividades dogmáticas. 0 problema é que a força retórica dos argumentos dogmáticos depende do fato de essas metáforas não serem apresentadas enquanto metáforas, mas como conceitos literalizados.

A noção de literalidade entre os juristas contemporâneos (os que pertencem às correntes teóricas assim chamadas pós-positivistas ou pós-modernas) parece inútil ou simplesmente irrelevante diante de sua impossibilidade ôntica ou mesmo semântica. Muito dificilmente um jurista teórico do século XX que desejasse ser levado a sério admitiria a possibilidade de obtenção de um sentido literal a partir de uma mera exegese dos textos de um documento normativo. Mesmo que se admita a interpretação literal como parte integrante de um dado método hermenêutico, dificilmente haveria expectativa de que seu resultado fosse uma compreensão fixa ou unívoca de uma palavra ou de um texto. No século $\mathrm{XX}$, a interpretação literal só pode ser admitida teoricamente como um exercício sobre as letras que leva a um resultado, ou mais de um resultado, todos contingentes e histórica ou pragmaticamente comprometidos. No âmbito da dogmática jurídica, podemos entender o método da interpretação literal apenas como expediente estratégico de busca de um sentido que seja satisfatoriamente persuasivo e que esteja em conformidade com um propósito determinado de resolver um caso específico.

Entretanto, como visto, para o desenvolvimento de um estudo da linguagem figurada do direito, paradoxalmente, a ideia de literalidade é fundamental. Mesmo que o sentido literal seja tomado como o sentido-que-é-diametralmente-oposto-ao-literal ou o simplesmente sentido não-figurado (GIBBS Jr., 2002). Se não fosse a noção de literalidade, de sua possibilidade, mesmo ideal, não seria possível falar em metáforas, metonímias, sinédoque, ironia ou qualquer outra figura de linguagem, de retórica ou de pensamento. 
Portanto, a dissolução da falsa dicotomia literal/metafórico (PALMA, 2004, p. 38-40) depende de uma concepção que combine critérios semânticos e pragmáticos e que procure eliminar diacronicamente a distinção literal/metafórico para considerar os enunciados em pé de igualdade com sua referência. Essa seria uma postura retórica adequada para a compreensão da relação entre a necessidade de adotar uma atitude literalizante e a capacidade de, ao mesmo tempo, saber lidar com uma linguagem figurada.

A dogmática privatista que se apoia fortemente na "vasta e imponente literatura civilística" tem, em razão de seu arsenal conceitual extremamente refinado, cuja autoridade remonta às instituições do direito romano, um lugar de destaque garantido na "direção ontológica do positivismo" (ADEODATO, 1996, p. 196). A tradição que se formou na Modernidade com as teorias positivistas ainda deixa marcas na maneira de pensar o direito, sobretudo no que se refere à produção do direito (fixação de textos dotados de validade, interpretações institucionais, argumentações judiciais, decisões, cumprimento de ordens etc.).

Tradicionalmente, pois, os juristas são levados a compreender o sentido literal dos textos normativos como algo fundamental a sua interpretação. É o caso de Karl Larenz (1997, p. 450) para quem toda interpretação de textos deve iniciar com o sentido literal. Larenz certamente não é um autor preocupado em identificar um caráter metafórico da linguagem jurídica. E muito provavelmente, procura construir sua tese atribuindo à literalidade dos sentidos dos textos normativos uma importância fundamental.

Segundo Larenz, a comunicabilidade e a compreensibilidade são garantidas pelo recurso ao sentido literal. Sua tese é de que a literalidade dos enunciados se perfaz pelo uso linguístico geral ou pelo uso linguístico especial. A literalidade é determinada então pelo uso linguístico das expressões no sentido em que são comumente entendidas. Mas para isso seria determinante pressupor que o legislador "se dirige ao cidadão e deseja ser entendido por ele". Se o direito se dirige a todos, deve ser dotado de um mínimo de compreensibilidade geral. Por essa razão "a linguagem das leis não pode afastar-se tanto do uso linguístico geral como ocorre com a linguagem de algumas ciências" mesmo que essa linguagem não seja capaz de alcançar a exatidão de uma linguagem simbolizada. 
Para Larenz, o fato de a linguagem jurídica ser derivada ou, nas suas palavras, ser "um caso especial da linguagem geral" é uma característica tanto de sua força quanto de sua fraqueza. Isso porque a linguagem geral (natural) é flexível, rica em cambiantes e capaz de se adaptar semanticamente. Em razão dessas características, não seria possível, segundo o autor, obter um sentido literal inequívoco meramente a partir do uso linguístico. Seria preciso recorrer ao contexto discursivo, aos co-textos e aos elementos concretos ou circunstanciais de um caso. E para isso, de qualquer forma, Larenz não abre mão de uma metáfora teórica para explicar esse processo de "olhar para frente e para trás" ou do "círculo hermenêutico".

Pode-se entender a linguagem jurídica não como um complexo de metáforas, mas como um idioma, isto é, uma linguagem diferenciada por pertencer ao contexto de determinada tecnologia, prática social ou área do conhecimento. As palavras então teriam um significado especial por pertencerem a um idioma específico, o que não faria com que os seus sentidos fossem figurados. Em um idioma, os sentidos especiais são também literais, mesmo que circunscritos a um âmbito determinado. Mas, logo identificado qual o contexto (técnico, prático ou teórico), o sentido literal poderia imediatamente ser identificado. Várias expressões que formam esse idioma podem representar as, assim chamadas, "metáforas mortas".

É possível, contudo, pressupor o contrário. As metáforas que teriam dado origem a um suposto idioma - no nosso caso, a linguagem especializada da dogmática jurídica - continuam vivas (se é que há pertinência em manter alguma diferença entre metáforas vivas e mortas) e exercem todo seu poder figurativo na elaboração e interpretação dos discursos jurídicos. Dessa forma, seria possível afirmar que os enunciados jurídicos se comportam mais de maneira metafórica do que idiomática.

As transformações semânticas proporcionadas pela passagem de uma linguagem natural para uma linguagem especializada da dogmática jurídica certamente têm também como escopo fundamental dotar esta última de um tom solene. 0 caráter metafórico dessa linguagem especializada ressalta a formalidade e a gravidade de seus enunciados, fazendo parecer mais importante do que poderia de fato ser. A opinião de Aristóteles (1996, p. 301 [1404b]), nesse sentido, parece relevante: 
[...] definimos qualidade do estilo a clareza (o discurso é uma forma de sinal e, portanto, se não se esclarece não desempenhará sua própria função). [...] Entre nomes e verbos, determinam a clareza aqueles usados em sentido próprio, enquanto os outros termos, dos quais se falou na Poética, deixam o estilo mais ornamentado do que humilde, dado que o desvio do uso prevalente faz com que pareça mais solene.

Ainda segundo Aristóteles (1996, p. 319 [1408a]),

Um estilo apropriado torna crível uma questão, posto que as almas dos ouvintes tiram falsas conclusões, como se o orador estivesse dizendo a verdade, dado que esses experimentam as mesmas disposições em tais circunstâncias e, por conseguinte, creem que as coisas sejam como diz quem fala, mesmo se não são assim, e o ouvinte compartilha sempre as emoções do orador, mesmo se este não diz coisa alguma. (...) Os ouvintes se impressionam também com expressões que os logógrafos utilizam insaciavelmente como "quem não sabe disso?", "todos sabem...", porque o ouvinte, por um sentimento de vergonha, se vê de acordo com o orador para poder condividir aquilo de que todos os outros participam.

Ou seja, o uso do estilo próprio da linguagem especializada da dogmática jurídica é uma maneira de persuadir o auditório por meio da conjunção entre lógos e páthos. A empatia entre orador e auditório depende do uso apropriado do estilo retórico da dogmática. É como se o auditório estivesse pronto para receber aquelas palavras porque adequadas em um estilo que é próprio àquele contexto. Quando, por exemplo, o orador do discurso jurídico-dogmático constitucional usa expressões como "princípio da razoabilidade" ou "dignidade da pessoa humana", por mais que não se refira objetivamente a nada de claro ou concreto, consegue angariar a simpatia do seu público que tampouco é capaz de determinar objetivamente o que essas expressões querem dizer literalmente, mas se sentem confortáveis diante delas. As palavras "razoável" ou "dignidade" próprias de um vocabulário comum ordinário recebem uma conotação especial ao pertencerem ao idioma da dogmática jurídica.

No entanto, o recurso à linguagem metafórica não é apenas uma questão de estilo, nem está relacionado apenas a uma função ornamental da retórica, mas deriva da própria maneira pela qual pensamos e construímos retoricamente o direito. 
O conceito é violento em relação ao fenômeno se deste não se origina. Já a metáfora é indiferente em relação ao fenômeno. É dessa forma que a linguagem jurídica figurada se revela potencialmente eficiente para moldar o mundo de acordo com sua própria realidade logóica ou discursiva.

0 ponto de vista contrário ao desta tese, isto é, que não vê metáforas na noção de direito, ou que não vê o próprio direito como metáfora, mas como um conjunto sistemático de conceitos, poderia recorrer ao argumento de que não há metáforas na linguagem jurídica simplesmente porque o que há são "metáforas mortas" e essas, segundo Max Black (1993, p. 25), por exemplo, não seriam de forma alguma metáforas. Deixaram de ser metáforas no momento em que se literalizaram, isto é, no momento em que se tornaram sentidos convencionais da linguagem. Assim, as expressões fonte do direito, processo judicial, ordenamento jurídico, se um dia foram metáforas necessárias ao desenvolvimento de novos conceitos jurídicos práticos e teóricos, no momento em que o seu uso passa a ser convencional, deixaria de estar presente o elemento inovador e sugestivo em termos conotativos necessários à constituição da metáfora. Pessoa jurídica deixaria de ser uma metáfora, ou, mais propriamente, exemplo de catacrese, e passaria a ser um conceito dotado de um sentido literal próprio da linguagem dogmática do direito.

Entretanto, metáforas mortas são metáforas ainda, mesmo que "mortas" (seja lá o que a própria metáfora da "morte" queira dizer). Black rejeita a expressão e sugere critérios mais refinados de discriminação: no lugar de viva ou morta, seria mais apropriado falar em extinta ou ativa. E mesmo assim ele diz não esperar muito desse esquema classificatório, nem de um seu substituto ainda mais refinado. No entanto, o próprio Black, talvez ironicamente, afirma que concentrará seus estudos apenas nas "metáforas que não precisam de respiração artificial, reconhecidas por falante e ouvinte como autenticamente 'vitais' ou ativas" (BLACK, 1993, p. 25), evidenciando claramente que alguma pertinência há na expressão "metáfora viva", a qual, em uma relação de oposição, suscita consequentemente a noção de "metáfora morta". Sem falar que catacrese pode-se considerar uma espécie de metáfora, mesmo que de metáfora corriqueira ou pouco original. 
Assim, contrariando o que diz Max Black, considero que inúmeros conceitos os quais se costuma chamar "metáforas mortas" são exemplos clássicos de palavras que ainda têm raízes metafóricas bastante vivas (GIBBS, 2002, p. 10). A propósito, entendo que é justamente essa vitalidade metafórica dos conceitos jurídicos que permite a evolução ou a mutação de conceitos fundamentais para a noção ocidental que temos de direito como família, justiça, bem jurídico, honra etc. Claramente há conceitos jurídicos que lutam contra qualquer evolução ou mutação semântica e permanecem quase intactos ao longo de séculos, mas esses conceitos perdem eficácia diante de novas expectativas políticas, sociais, econômicas ou culturais. É assim com os conceitos de enfiteuse, ou de servidão no direito civil, por exemplo.

Destarte, a formalização da linguagem jurídica é um modo de metaforização da própria linguagem do direito. Podemos arriscar dizer que é metafórico falar em uma lógica do direito, na medida em que não há verdadeiras relações de implicação (lógica) no pensamento jurídico. A lógica é algo "deslocado" no direito - isto é, seu emprego é metafórico não só no vocabulário jurídico, mas também nas formas jurídicas de compreensão. As relações supostamente lógicas que são evidenciadas são provavelmente ilustrações intuitivas (figuras, imagens) de uma relação possível a que se quer atribuir o peso epistêmico de uma estrutura logicamente garantida.

Nem sempre se pode dizer que as formulações do pensamento dogmático são guiadas por alguma forma de racionalidade propriamente lógica. A produção jurídica esparsa no tempo e espacialmente fragmentária, a despeito do que dizem as concepções sistêmicas da teoria, dificilmente pode garantir um grau de coerência necessário para que se possa falar em lógica no sentido tradicional da palavra. E, sem coerência, só formas bizarras ou inusitadas de lógica serão pertinentes. 0 que chamamos de direito positivo, empiricamente identificável numa comunidade, não é direito por ser lógico ou racional (do contrário tudo o que não se justificasse racionalmente ou que perturbasse algum postulado lógico seria desde sempre juridicamente inválido, por ser falso). Sem falar que as teses racionalistas do direito são metafísicas ou jusnaturalistas, justamente porque dificilmente se encontrará uma situação de ordenação ou 
coerência na totalidade de um direito positivo. 0 racional não é condição de validade para o direito numa visão não-jusnaturalista. Portanto, a produção do direito não é necessariamente lógica, nem racional, tampouco coerente (ou pelo menos não precisa ter essas características para que seja reconhecido como válida). Aliás, não é o fato de ser ou não ser racional que faz do direito algo legítimo ou correto, ou, em uma palavra, justo.

\section{A proibição e o desestímulo do estudo da retórica entre os juristas como paradoxo}

O preconceito moderno contra a retórica se estende necessariamente à linguagem metafórica ou figurada como um todo no campo do pensamento científico. É como se, para o desenvolvimento da ciência, apenas os ideais retóricos de ordem e clareza fossem de alguma utilidade aos discursos científicos e à produção de conhecimento que se diz objetivo. Assim, a ciência moderna caracteriza-se por sua oposição à retórica.

Essa é, pois, a posição de John Locke, cujo pensamento pode ser considerado um dos marcos da filosofia da ciência moderna. Em An Essay Concerning Human Understanding, publicado pela primeira vez em 1690, Locke (1996, p. 214) parte do pressuposto não-retórico de que há uma separação nítida entre esperteza ou sagacidade (wit) de um lado e verdade seca (dry truth) e conhecimento verdadeiro (real knowledge) de outro. 0 preconceito que caracteriza a epistemologia moderna se funda nessa distinção entre discursos que produzem entretenimento, buscam prazer e deleite e discursos que proporcionam informação e aperfeiçoamento. Para Locke, os abusos proporcionados pela linguagem artificial da retórica, que deturpam a produção do conhecimento objetivo e mascaram a realidade, só são admitidos porque nós buscamos, nos discursos, mais entretenimento do que informação. Mas, ainda segundo o filósofo inglês,

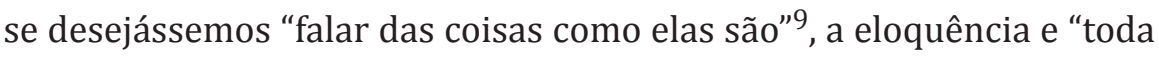
a aplicação artificial e figurativa das palavras"10 não teriam qualquer valor, senão no que se refere a ordem e clareza. Os discursos figurados e o uso impróprio da linguagem seriam assim apenas meios de se insinuar ideias erradas, mover as paixões e desencaminhar os julgamentos, ou seja, segundo o próprio Locke, uma maneira perfeita de se trapacear. 
Evidentemente essa é uma crítica não só típica da origem do pensamento moderno como também necessária ao momento histórico em que foi produzida. Sabe-se que a eloquência pode ser empregada tanto para a produção de discursos com pretensões à verdade como para o engodo. Não é tipicamente característico dos discursos retóricos a finalidade de mentir, enganar ou se desviar da realidade. No século XVII, entretanto, era preciso deixar claro qual o papel da linguagem na ciência, isto é, na produção de conhecimento verdadeiro para distingui-la essencialmente de qualquer forma de charlatanismo ou faladeira infundada. A retórica, como se sabe, terminou por ser vulgarmente identificada com o discurso de charlatães e mentirosos, e assim o discurso científico, se intrinsecamente ligado à ideia de produção de conhecimento verdadeiro, não deveria ser contaminado por qualquer forma de expediente retórico. A retórica é, pois, para Locke (1996, p. 215) um "poderoso instrumento de erro e fraude"11 que se sustenta porque os indivíduos "amam enganar e serem enganados"12.

Esse posicionamento epistemológico típico do início da Modernidade filosófica hoje dificilmente se sustenta filosoficamente, desde que se compreenda que também o discurso científico é uma forma de retórica.

Há quem tenha sustentado não ser propriamente a arte retórica responsável pelo engano, pelo erro ou pela fraude, mas a própria linguagem. 0 "bom senso iluminista"13 (ECO, 1998, p. 26), sintetizado pelo romancista italiano Alessandro Manzoni ainda no século XIX, é que parece ter fundamentado a origem do preconceito contra a arte do discurso. Isto é, contra a semiose que depende de uma ars ou téchne. Manzoni apresentava como diferentes a semiose natural exercida pelos humildes de forma praticamente instintiva e a semiose artificial da linguagem verbal incapaz de dar conta da realidade ou responsável por mascará-la objetivando geralmente o poder. Mas não propriamente em razão da técnica e sim por conta da própria natureza da linguagem verbal, apta a contaminar até mesmo a semiose natural da própria experiência. A linguagem verbal quando rediz e interpreta a realidade empírica terminaria assim por contaminar a semiose natural, fazendo com que esta induzisse a erro e equívoco (ECO, 1998, p. 27). Nesta visão, as palavras mesmas, pois, seriam enganosas. 
Evidentemente essa distinção tem por fundamento uma epistemologia simplória, dificilmente defensável atualmente, que sustenta a tese de uma realidade válida em si mesma independente de qualquer forma de linguagem verbal e de seus corolários. Na verdade, pode-se dizer que Manzoni parte do pressuposto de que os artifícios linguísticos são responsáveis por mascarar a realidade (EC0, 1998, p. 28) e de que os relatórios verbais são enganadores por natureza (EC0, 1998, p. 29). No romance Os noivos (I promessi sposi), Manzoni dá a entender que a própria linguagem é "portadora de vento, se não de mentira" (ECO, 1998, p. 30). Se a linguagem verbal é ela mesma responsável pelos enganos e pela mentira, o que dizer então da arte de manipulá-la?

Jonathan Swift é profundamente irônico em relação a esse ponto de vista tipicamente moderno que separa o âmbito da retórica e da linguagem voltada ao deleite do âmbito da informação acerca de fatos e da realidade, isto é, que coloca de um lado os discursos e as narrativas alegóricas e de outro os relatos de dados empíricos e históricos. No final de As viagens de Gulliver, por exemplo, publicado originalmente em 1726, depois de narrar em primeira pessoa as estórias mais fantásticas e extravagantes e, até mesmo, bizarras, a personagem que dá voz ao autor diz, referindo-se ao leitor

Eu ofereci uma história fidedigna de minhas viagens por dezesseis anos e mais de sete meses; na qual eu não fui tão meticuloso com o ornamento quanto fui com a verdade. Eu poderia, talvez como outros, tê-lo maravilhado com contos estranhos e improváveis; mas, ao contrário, escolhi relatar simples matéria de fato da maneira e do estilo mais simples; porque meu principal objetivo era informar e não entretê-lo ${ }^{14}$ (SWIFT, 1994, p. 322).

A despeito do pensamento iluminista exemplificado na tradição filosófica e literária em Locke e Manzoni respectivamente, entendo que, com técnica, retoricamente, mas também por talento ou simples instinto, aqueles que são capazes de dominar as metáforas da linguagem jurídica é que são os verdadeiros responsáveis pela produção do que se chama conhecimento jurídico. Não raro os juristas perdem-se em suas teias de conceitos, cada vez mais distantes do que se pode chamar de "mundo empírico", e mesmo do senso comum da semiose natural aludida por Man- 
zoni. Basta pensar em como é a "linguagem do direito", ou melhor, basta pensar no "direito enquanto linguagem", isto é, no direito como linguagem especializada que só pode ser compreendida por quem nela já é iniciado.

O trabalho semiótico do jurista, pois, pode ser equiparado ao auxílio que presta um escrivão na comunicação entre dois iletrados que se correspondem ${ }^{15}$. Tanto o emissor da mensagem como o receptor recorrem a quem seja capaz de decodificá-la, isto é, a quem seja capaz de ler e escrever. Imagine-se que somente emissor e receptor têm conhecimento dos fatos tratados pela mensagem. Escritor e leitor são ambos escrivães que participam do processo de codificação e decodificação da mensagem oral em mensagem escrita, mas não estão a par do fato narrado. Isso, contudo, não quer dizer que eles não interfiram no sentido da mensagem. A autoridade de quem domina a escrita e a leitura é capaz de determinar como os fatos narrados - traduzidos em palavras faladas e depois em palavras escritas - serão escritos e serão lidos e, portanto, como serão entendidos. É uma situação que pode ser encarada como um jogo de adaptação de uma história às regras racionais da sintaxe.

No direito, a linguagem jurídica especializada também carece de interpretação e de tradução. E tudo isso depende da autoridade do intérprete que não sabe dos fatos, porque os fatos não chegam a ele. 0 jurista é o intérprete autorizado a dizer o que o texto jurídico significa e a determinar a chave de leitura pela qual os fatos devem ser decifrados. Mas perceba-se que a linguagem jurídica processual já não é mais a linguagem natural dos fatos, é apenas uma tradução feita pelo jurista prático, isto é, pelo técnico que domina aquela forma de linguagem especializada.

Assim, a retórica analítica vê o direito como ars ou téchne, isto é, como arte ou técnica de manipulação da linguagem (SCHLIEFFEN, 2006, p. 46; 2003, p. 722). Daí a ideia de dogmática jurídica como tecnologia e não como ciência.

De forma extremamente ampla, pode-se pensar como principal objetivo da ciência a construção de postulados sobre o mundo que sejam suficientemente livres de ambiguidade e que permita a dois cientistas diferentes chegar ao mesmo resultado usando métodos similares. 0 direito, muito precariamente, é capaz de produzir algo semelhante. Em primeiro lugar não há acordo sobre o método jurídico a ser empregado, 
mesmo em casos semelhantes; em segundo lugar, a aparente objetividade que decorre da ideia de legalidade, subsunção e imparcialidade é apenas uma forma de camuflar a subjetividade das escolhas; em terceiro lugar, a pretensão de neutralidade axiológica é um contra-senso, já que a prática do direito é exatamente escolha de valores e imposição de ideologias.

No que diz respeito à produção de conhecimento jurídico na prática, portanto, deixando de lado a ciência como um todo, a linguagem metafórica, como já discutido até aqui, parece ser não só de fundamental importância, como também indispensável à própria retórica do direito, não só a sua retórica material, mas também a suas retóricas prática e teórica.

Mesmo John Locke em sua crítica epistemológica à retórica termina por desenvolver um discurso que é evidente e fundamentalmente retórico, não só pelas suas óbvias pretensões de persuadir uma comunidade de leitores como também pelos recursos estilísticos e pelas metáforas que ele próprio critica, mas não deixa de empregar. 0 que é a "verdade seca" a que Locke se refere senão uma nítida metáfora? Como diferenciar ontologicamente com precisão uma linguagem "artificial" de outra "natural"? Não seria a noção de naturalidade já uma imposição de um modo particular de ver (imaginar, figurar) as coisas ou uma ideologia semântica determinada?

É evidente em Locke, sobretudo, a auto-disciplina de uma retórica iluminista na produção de seu discurso epistemológico (DE MAN, 1978, p. 12). No contexto do século XVII, pois, a filosofia, a ciência e todo discurso com pretensões de produção de conhecimento epistemologicamente fundamentado deveriam ser livres de qualquer forma de retórica. É como se apenas duas estratégias fossem admitidas: ou o discurso científico abdica de qualquer rigor de sua linguagem e admite o seu caráter inescapavelmente figurativo, portanto, impreciso e indeterminado; ou se liberta de toda e qualquer forma de figuração e desenvolve uma linguagem puramente literal e conceitual incapaz de "deturpar as ideias".

A proibição ou o desestímulo do estudo da retórica entre os juristas, portanto, foi um modo eficaz de contribuir para a exitosa persuasão provocada pela crença no lógos (discurso). A falta de familiaridade com as técnicas retóricas impede que os seus endereçados se imunizem contra ela. Todo discurso - do mais verdadeiro ao mais mentiroso - é uma 
forma de retórica. Verdade e mentira (e também a falsidade) são noções construídas discursivamente, isto é, retoricamente, seja por instinto, seja por técnica.

A repetição e a retroalimentação dos discursos da dogmática jurídica é fruto dessa crença pueril no próprio discurso e na linguagem que é empregada. 0 desconhecimento das estratégias próprias da arte retórica, portanto, leva à impossibilidade de um autêntico reconhecimento retórico. A formação do jurista, quando deixa de ser uma formação em retórica, cria uma situação paradoxal em que a retórica que o discurso jurídico produz é apresentada como não tendo caráter retórico ou discursivo. Como se a preparação do discurso (a escolha do estilo, das palavras, da disposição dos argumentos, dos pontos de partida para a argumentação, dos conectores lógicos, das conclusões, dos pressupostos, das estratégias, da oportunidade, dos meios de prova etc.) fossem simplesmente irrelevantes.

\section{A independência da verdade metafórica em relação aos enunciados literais}

Do ponto de vista retórico, portanto, a verdade na prática do direito deve ser considerada verdade metafórica. Enunciados metafóricos podem ser considerados verdadeiros mesmo diante de falsas inferências. A independência da verdade metafórica em relação a enunciados literais é o que garante a produção retórica de conhecimento no direito. Essa independência da verdade metafórica está relacionada à autonomia que os significados metafóricos têm em relação às tentativas de sua paráfrase literal.

Contra as teorias da comparação, que remontam a Aristóteles e defendem que enunciados metafóricos envolvem sempre uma comparação ou similaridade entre dois ou mais objetos, John Searle afirma que uma asserção metafórica não é necessariamente uma asserção de similaridade, nem o enunciado da comparação é parte do significado metafórico. Nem sempre se pode dizer que compreende-se uma metáfora porque se faz uma comparação entre o predicado da metáfora e o predicado de uma supostamente possível paráfrase literal. Ou seja, não é a relação de similaridade entre o os elementos do enunciado metafórico e os elementos 
de um enunciado literal que propiciam a produção de sentido. Segundo Searle (1993, p. 92), "asserções metafóricas podem se manter verdadeiras mesmo que se descubra que o enunciado de similaridade sobre o qual se baseia a inferência do significado literal é falsa ${ }^{16 "}$.

0 exemplo de enunciado metafórico dado por Searle é "Richard é um gorila", cuja paráfrase literal poderia ser elaborada como "Richard é feroz, sórdido, propenso a violência, e assim por diante". Suponha-se que a inferência que o ouvinte faz em relação à paráfrase é baseada na crença de que gorilas são ferozes, sórdidos, propensos a violência etc. 0 significado metafórico estaria justificado na comparação entre as características de Richard e as características de um gorila. A comparação, assim, supostamente, seria parte do padrão de inferência que possibilitaria ao ouvinte concluir que quando se disse que "Richard é um gorila", o que se quis significar ou dar a entender foi que "Richard é feroz, sórdido etc.". Suponha-se, entretanto, que se descubra que gorilas de forma alguma são animais ferozes ou violentos, mas, na verdade, tímidos, sensíveis e sentimentais. Isso faria com que a comparação entre Richard e um gorila fosse patentemente falsa.

0 que se disse sobre Richard continua verdadeiro, a despeito da precariedade da comparação e da ausência de similaridade entre ele e um autêntico gorila. Portanto, a asserção metafórica pode permanecer verdadeira mesmo diante do que se descobriu em seguida em relação às características autênticas de um gorila. As expressões que empregamos para expressar metaforicamente algum conteúdo semântico dependem das crenças que temos em relação ao que as coisas são. 0 enunciado "Richard é um gorila" se refere apenas a Richard e não a gorilas. A palavra "gorila" serve a transmitir ou produzir determinado conteúdo semântico diferente de seu próprio sentido.

São as crenças que os interlocutores compartilham em um diálogo, e não uma verdade ou realidade fora da metáfora e do discurso, que determinam o conteúdo semântico a ser transmitido por uma metáfora (FINGER, 1996, p. 44). No direito, expressões como liberdade, culpa, causalidade, dolo, igualdade, fonte, boa-fé etc. são empregadas metaforicamente e sua verdade metafórica depende dessa autonomia em relação a suas paráfrases literais. A epistemologia do conhecimento jurídico, 
isto é, do conhecimento elaborado na produção prática do direito, deve levar em consideração essa característica retórica do próprio direito e de sua linguagem figurada. Culpa pressupõe a noção de liberdade que por sua vez remete à ideia de autonomia e de livre-arbítrio. Apesar de toda a importância do conceito de culpa para a dogmática e de todas as consequências que decorrem de seu emprego na compreensão jurídica, dificilmente teremos alguma segurança em afirmar que somos realmente livres e que algum deus nos dotou de livre-arbítrio.

Independentemente de ser verdadeiro ou não o fato de sermos dotados de livre-arbítrio e de que conduzimos livremente as nossas ações, para os discursos jurídico-dogmáticos, a metáfora da culpabilidade é verdadeira. Ela torna-se, enquanto conceito estruturado metaforicamente, a despeito de qualquer garantia de literalidade, uma noção instrumental para o operar do próprio raciocínio jurídico.

As metáforas determinam o rumo que uma argumentação ou uma pesquisa científica pode tomar. É um jogo dialético no qual metáforas são ao mesmo tempo causa e efeito de um único processo de desenvolvimento ideológico, tecnológico e científico.

Se efetivamente "conceituar é aprisionar uma realidade que, a rigor, não pode ser aprisionada” (ADEODATO, 1996, p. 194), podemos afirmar que a realidade do conceito de direito se deixa apreender apenas relativamente pelo efetivo caráter pragmático e operacional de suas próprias metáforas. É nesse sentido que se torna possível estabelecer uma filosofia retórica do direito por meio de uma epistemologia da metáfora capaz de propiciar conhecimento retórico no âmbito jurídico, isto é, no domínio da produção do direito. Com uma epistemologia retórica, pois, seria possível desenvolver uma semântica própria da metáfora, isto é, uma metodologia capaz de tornar pertinente a ideia de um sentido propriamente metafórico, independente até de qualquer forma de literalidade. Uma semântica autônoma da metáfora, portanto, faz com que a determinação do sentido figurado ou metafórico independa da determinação prévia de um sentido literal.

Do ponto de vista hermenêutico, não há muita coerência em se afirmar que toda interpretação inequívoca dependa sempre do emprego de uma linguagem literal, nem que toda linguagem figurada produza sem- 
pre uma situação de indeterminação ou ambiguidade. Nem Aristóteles sustenta esse tipo de tese, mesmo considerando, como vimos, que seja a clareza a virtude do discurso retórico (ARISTÓTELES, 1996, p. 301 [1405a]) e a qualidade do estilo, já que "o discurso é uma forma de sinal e, portanto, se não esclarece não desempenhará a própria função” (ARISTÓTELES, 1996, p. 199 [1404b]). Quer dizer, o sinal só teria sentido se fosse claro. Mas a clareza não é atributo exclusivo de enunciados literais.

O próprio Aristóteles (1996, 303 [1405a]) afirma ainda que "a metáfora, em particular, possui clareza, agradabilidade e algo de exótico, e não se pode apreender o seu uso a partir de outro qualquer". Ou seja, ao mesmo tempo em que é exótica e, portanto, causa espanto, a metáfora é clara e se faz compreender sem maiores dificuldades hermenêuticas, mesmo diante de uma potencial situação de semiose ilimitada. Aristóteles, pois, mesmo com todo seu rigor acadêmico, reconhece a importância do ponto de vista retórico-pragmático da metáfora para a efetividade dos discursos. Mesmo Platão, que é representado muitas vezes como um inimigo da retórica e menos sensível do que Aristóteles em relação ao estudo da persuasão, reconhece igualmente a força da palavra na filosofia e a importância de se elaborar bem um discurso na produção de conhecimento.

Giovanni Casertano, por exemplo, sustenta que em Platão a verdade é sempre verdade discursiva: "O discurso permanece o único palco onde se representa a vida da verdade." Os aspectos discursivo e dialético da verdade se destacam inclusive quando Platão se refere à "verdade dos fatos" ou à "verdade das coisas" ou à "verdade em si mesma", pois fica claro o seu objetivo retórico de persuadir o leitor, ao recorrer a essas expressões, ao refutar as verdades aparentes típicas das "palavras dos feirantes, dos magos ou simplesmente dos patifes” (CASERTANO, 2010, p. 13).

Ainda segundo Casertano, "não é estranho que não se encontre uma definição de verdade em Platão, porque a verdade, como se diz mais do que uma vez nos diálogos, é questão de deuses, não de homens", mas "dizer que a verdade é somente dos deuses e não dos homens não significa renunciar à verdade" (CASERTANO, 2010, p. 14). Casertano (2010, p. 18) sustenta que "na obra platônica nunca há uma verdadeira e efetiva definição de 'verdade', mas apenas de 'discurso verdadeiro'”. 
Quando Platão propõe a verdade como "verdade discursiva", leva em consideração a difícil relação entre verdade e persuasão. Os discursos verdadeiros devem ser igualmente persuasivos, pois ao mesmo tempo em que se deve informar, deve-se também persuadir. É o que se pode depreender da defesa de Sócrates diante do tribunal popular. Sócrates, segundo Platão teria dito "Mas, pondo de parte, senhores, a questão da honra, não me parece decoroso implorar ao juiz e alcançar a absolvição por meio de súplicas, em vez de procurar instruí-lo e convencê-lo ( $\delta \iota \delta \alpha ́ \sigma \kappa \varepsilon \iota v ~ \kappa \alpha i$

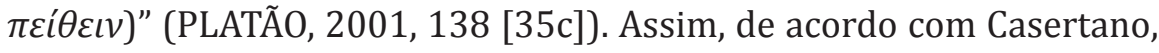
"acerca da verdade não basta um consenso puramente nominal, mas é necessário ser persuadido de verdade" (CASERTANO, 2010, p. 21).

E a persuasão, por sua vez, depende, dentre outros elementos, do recurso à linguagem figurada e da força do lógos, inclusive no discurso teórico, filosófico ou científico. Essa é a opinião fundamentada de Mary Hesse e Michael Arbib (2008, p. 15):

Nós sustentamos que não existe qualquer dicotomia estrita entre a linguagem literal ou científica de um lado e a linguagem metafórica do outro. Não usamos "metáfora" como um termo pejorativo. Ao contrário, sempre que usamos a linguagem, há uma riqueza de associações que vai além de qualquer noção do que poderíamos chamar sentido "literal". (...) gostaríamos de ver o sentido literal mais como limite de um continuum da metáfora do que na qualidade de uma forma de significado distinguida nitidamente a partir da qual a metáfora deveria ser definida como um desvio. Em particular, sugerimos que boa parte da nossa compreensão da linguagem repousa na nossa condição de pertencer a um sistema simbólico holístico codificado nos esquemas em nossas cabeças, muitos dos quais assimilados inconscientemente. Nosso uso da linguagem repousa não em definições precisas, mas no (não necessariamente consciente) uso de esquemas que resultaram de ricas e complexas interações com uma realidade física e social de modo algum livres de ambiguidades ${ }^{17}$ (ARBIB; HESSE, 2008, p. 15).

Apesar de a noção de clareza parecer fundamental para a epistemologia moderna, como na filosofia de base cartesiana que se baseia concepção metafórica de "ideias claras e distintas", fazendo da clareza uma virtude em si mesma, isso não significa dizer que a linguagem epistêmica só seja constituída por um arsenal conceitual absolutamente definido. Os conceitos com os quais, em muitos casos, procuramos capturar a 
realidade são inerentemente deficientes em suas definições. 0 modelo de decisão que tomamos da matemática e da lógica formal é baseado na noção de inferência a partir de fatos inequívocos ou axiomas, aplicando regras previamente fixadas. Entretanto é preciso considerar que os matemáticos trabalham com conceitos abstraídos da realidade empírica sem qualquer pressão do tempo, enquanto os juristas precisam trabalhar com decisões temporalmente limitadas e com informações não apenas incompletas como também inconsistentes.

Esse seria o panorama geral da epistemologia na produção do direito. As decisões pouco têm a ver com a coerência lógica entre axiomas, ou, no caso do direito moderno, dogmas.

Contudo, dificilmente, no âmbito da prática jurídica, as decisões partem de "fatos inequívocos". Especialmente porque no âmbito da retórica (se a arte do direito é parte da retórica, logo é uma arte retórica) não há espaço para fatos incontrovertidos.

Ao invés de conceitos claros e bem definidos os juristas são obrigados a lidar com uma linguagem, por vezes, instável. Seria até curioso falar em conceitos jurídicos "determinados". Talvez a noção de conceitos determinados no direito só tenha pertinência para suscitar uma discussão metodológica em torno dos conceitos indeterminados, isto é, desenvolver métodos que possibilitem ao jurista manipular esses conceitos e aprender a lidar com as situações de indeterminação. A própria noção de clareza tem sua origem numa metáfora visual que pode ser impertinente em relação a outros sentidos, como o olfato e o tato, por exemplo.

E não são apenas as teorias retóricas do direito que alertam para a provável inexistência de conceitos determinados no direito. Mesmo as teorias positivistas compreendem bem esse problema. Das palavras de Karl Engisch (1996, p. 208), como bom exemplo de um teórico positivista, é possível chegar a essa conclusão.

Os conceitos absolutamente determinados são muito raros no direito. Em todo o caso devemos considerar como tais os conceitos numéricos (especialmente em combinação com os conceitos de medida e os valores monetários: $50 \mathrm{~km}$, prazo de 24 horas, 100 marcos). Os conceitos jurídicos são predominantemente indeterminados, pelo menos em parte. É o que pode afirmar-se, por exemplo, a respeito daqueles conceitos naturalísticos 
que são recebidos pelo direito, como os de "escuridão", "sossego nocturno", "ruído", "perigo", "coisa". E com mais razão se pode dizer o mesmo dos conceitos propriamente jurídicos, como os de "assassinato" ("homicídio qualificado"), "crime", "acto administrativo", "negócio jurídico" etc. Com Philipp Heck, podemos distinguir nos conceitos jurídicos indeterminados um núcleo conceitual e um halo conceitual. Sempre que temos uma noção clara do conteúdo e da extensão dum conceito, estamos no domínio do núcleo conceitual. Onde as dúvidas começam, começa o halo do conceito.

Podemos ver no texto de Engisch acima que a metáfora da clareza permanece útil para a definição de determinação e indeterminação. Mas as noções metafóricas de clareza, de núcleo e de halo conceitual são pertinentes para definir o que seja a determinação de um conceito, ou são simplesmente expedientes meramente didático-pedagógicos de apresentação do problema para alunos iniciantes no estudo do direito, isto é, uma forma alegórica de apresentar a questão para os não iniciados ou um público ainda não familiarizado com as situações correntes de indeterminação do direito?

O próprio Engisch (1996, p. 205) reconhece que "no domínio do direito e do seu conhecimento, há uma série de fenômenos que fazem do próprio princípio da investigação da verdade um problema, que fazem com que os limites de um conhecimento puramente científico apareçam aos nossos olhos como uma 'linha de penumbra'”.

Como discutido até o momento, metáforas, longe de representarem afirmações absurdas sobre o mundo, são produtoras de sentido e consideravelmente funcionais nos processos de comunicação entre os seres humanos. Nada obstante, o sentido metafórico ou figurado é normalmente equiparado a uma forma especial de sentido oculto ou velado e até mesmo misterioso. Se as metáforas então produzem um sentido, mas esse sentido sempre será, de alguma forma, velado, quer dizer que elas, ao mesmo tempo em que são úteis à comunicação humana, representam um empecilho à troca efetiva de mensagens (assumindo que a tese de que a comunicação se dá por troca de mensagens entre interlocutores).

0 terreno da linguagem metafórica, pois, mesmo diante de situações de clareza, pode ser fecundo para a proliferação de superinterpretações. E a despeito do que pensam os juristas iluministas e os pensadores 
analíticos, as superinterpretações são valiosas para o desenvolvimento do direito. 0 problema reside em distinguir as superinterpretações que representam possibilidade de mudança ou adequação do direito a diferentes realidades, e aquelas que são consideradas um equívoco ou exagero do intérprete. Mas é justamente o poder de romper com uma semântica ordinária que permite a criação do direito e a especialização da linguagem dogmática.

Entre os juristas não é incomum perceber interpretações mais ousadas ou que extrapolam o sentido convencional ou os limites de uma semântica ordinária. Apesar da origem na linguagem comum ou natural, a evolução da linguagem especializada da dogmática jurídica depende justamente dessa liberdade interpretativa e da variação semântica que as metáforas possibilitam. 0 mais importante, porém, é saber se se trata de uma metáfora mesmo, ou de uma simples frase perfeitamente descritiva de um estado de coisas.

Em vários momentos, as metáforas também funcionam como expedientes descritivos, isto é, são utilizadas com a intenção de descrever ou explicar algo do mundo (PALMA, 2004, p. 9). Isso quer dizer que mesmo a ciência utiliza as metáforas não apenas como mero adorno ou acessório, mas como maneira eficaz de transformar o observado em descrito. As metáforas epistêmicas seriam responsáveis por essa tarefa de, por meio de um processo figurativo, representar e traduzir uma realidade supostamente objetiva em um lógos tipicamente intersubjetivo como é o discurso científico.

As metáforas epistêmicas do direito não podem ser tratadas como um simples "tû-tû", por mais que o seu significado seja de difícil explicação. Por outro lado, se o "tû-tû" pode ser considerado uma "força ou estigma perigoso" (ROSS, 2004, p. 14), as metáforas do direito também apresentam alguma forma de força retórica. De acordo com Alf Ross, o discurso jurídico, em muitos de seus aspectos, assemelha-se aos discursos gerados em torno da noção de "tû-tû". Assim como "tû-tû" pode não ser nada, ou ser entendido como uma palavra desprovida ou carente de significado, e o discurso que o emprega destituído de sentido, seria também o discurso jurídico destituído de sentido quando emprega palavras como "propriedade”, “direito subjetivo", “crédito" ou "dever” (ROSS, 2004, 
p. 28, 31, 44). Do ponto de vista pragmático, contudo, ambas as formas de discurso seriam capazes de cumprir a sua função, mesmo diante da carência de significado das expressões empregadas em sua constituição. Segundo Ross, enunciados que incluem a palavra "tû-tû" são capazes de preencher as funções prescritiva e descritiva da linguagem, isto é, expressar ordens ou regras e fazer afirmações sobre fatos.

Obviamente Ross parte em princípio de uma teoria semântica (evidentemente não retórica) preocupada apenas com o sentido literal para depois permitir a elaboração de uma pragmática do discurso (apenas precariamente retórica). A ideia de referência semântica como sendo o estado de coisas ao qual uma frase se refere (ROSS, 2004, p. 16) e a pressuposição de que há uma diferença entre algo existente na realidade e algo meramente imaginado são pressuposições fundamentais para a elaboração de sua crítica. Mesmo assim, ele admite que a referência semântica dependerá dos usos linguísticos, ou seja, de uma pragmática (o que reforça, mesmo que involuntariamente, a tese da retórica).

Ainda que a palavra "tû-tû" em si mesma careça de qualquer significação, os enunciados nos quais aparece não são formulados casualmente. Como outros enunciados de afirmação, são promovidos, em conformidade com os costumes linguísticos predominantes, por estados de coisas perfeitamente definidos. Isso explica por que enunciados que incluem a palavra "tû-tû" possuem referência semântica, ainda que a palavra careça de sentido (ROSS, 2004, p. 19).

Isso equivaleria a dizer que independentemente do significado que "tû-tû" venha a ter para aquela comunidade em que a expressão é empregada, o importante é levar em consideração que "estar tû-tû" pode corresponder à descrição de um estado de coisas: ter ingerido alimento do chefe, matado um animal totêmico, ou encontrado a sogra; ou a uma prescrição de outro estado de coisas: a necessidade de ser submetido a um ritual de purificação (ROSS, 2004, p. 20). Pode-se, portanto, atribuir uma referência semântica ao enunciado "Fulano está tû-tû", indicando certo estado de coisas, sem que a própria expressão seja definida. Para Ross (2004, p. 26), "independentemente do fato de a palavra carecer em si de referência semântica e, independentemente das ideias de forças 
místicas conectadas à palavra, os enunciados nos quais ela aparece podem atuar, contudo, efetivamente como expressões prescritivas e descritivas".

Uma maneira de simplificar o discurso e purificá-lo de qualquer misticismo seria substituir os enunciados "aquele que mata um animal totêmico torna-se tû-tû" e "quem está tû-tû deverá submeter-se a uma cerimônia de purificação" pela enunciação direta "aquele que mata um animal totêmico deve submeter-se a uma cerimônia de purificação". Mas Ross (2004, p. 27), em seu célebre e jocoso ensaio, entende que, mesmo que a noção de "tû-tû" não passe de mera ilusão, do ponto de vista pragmático, esse não seria o caso.

Para Ross (2004, p. 31), pois, a palavra "crédito", por exemplo, é equiparável a "tû-tû", dado que ambas não são "coisas reais": "é simplesmente uma palavra, uma palavra vazia e desprovida de qualquer referência semântica. Do mesmo modo, nossa afirmação de que quem toma o empréstimo torna-se obrigado corresponde à afirmação da alegórica tribo de que a pessoa que mata um anima totêmico se torna tû-tû".

É por essa razão que ele afirma que "nossa terminologia e nossas ideias apresentam uma considerável semelhança estrutural com o pensamento mágico primitivo, com respeito à invocação de potências sobrenaturais, as quais, por sua vez, são convertidas em efeitos fáticos" (ROSS, 2004, p. 32). Esse caráter mágico, comparável ao poder retórico das metáforas, pode estar relacionado ao poder que a linguagem exerce no pensamento.

Talvez esse aspecto não tenha merecido a devida atenção por parte de Ross e do positivismo realista em geral. 0 caráter mágico ou místico da própria linguagem é também uma realidade, talvez não no sentido dado pela escola realista, mas no sentido retórico da realidade construída discursivamente pela persuasão. Sobretudo no caso da realidade do direito. Se de fato é possível dizer, assumindo uma perspectiva puramente semântica, que "propriedade nada representa, em absoluto, e não existe relação causal ou lógica entre o suposto fenômeno da propriedade e as mencionadas consequências jurídicas" (ROSS, 2004, p. 44), por outro lado, a própria metáfora da propriedade não admite paráfrase. Assim como "tû-tû" não pode ser substituído por outra expressão, "propriedade", "direito subjetivo" ou "crédito" são construções metafóricas fundamen- 
tais para a retórica material do direito e independem de uma realidade autônoma que lhe seja exterior.

Contrariamente ao que diz Ross (2004, p. 47), "propriedade" não é uma expressão que pode ser substituída por "queijo velho" ou "tû-tû", pois, enquanto metáfora que compõe o vocabulário do direito, representa não só uma expressão verbal, mas um modo próprio de pensar do jurista. De forma que a palavra, com seu sentido figurado, cria a sua própria realidade sem que seja entendida como mera ilusão. Se "propriedade" ou "direito subjetivo" não são fatos, podem ser considerados fundamentais na construção de fatos a partir de uma semântica própria de um sentido metafórico. 0 que entendemos por fato é já uma construção retórica que depende da convicção de que um estado de coisas é de tal forma.

É importante notar, claro, que as críticas de Ross à linguagem empregada pelos juristas em suas performances discursivas na construção da realidade conceitual do direito são impregnadas de moderno preconceito ocidental que o faz considerar, desde um ponto de vista típico de seu contexto, a ciência e a linguagem científica como a única forma de discurso válido para representar e afirmar a realidade. A atitude cientificista do positivismo realista de Ross impede-o de tratar com seriedade problemas que não se adéquam a sua metodologia ou que não se fundamentam epistemologicamente de acordo com os critérios considerados válidos pela dita "comunidade científica".

Para Ross, pois, se para uma palavra não há referência semântica a um estado de coisas da "realidade" empírica, então o conceito é simplesmente insignificante, mesmo que não seja inútil ou supérfluo. Evidentemente, as teorias que assumem uma atitude cientificista constroem uma retórica impregnada do preconceito de que aquilo que não é científico é necessariamente destituído de valor cognitivo.

\section{Conclusão}

Vimos que não é uma tarefa simples determinar o que seja o sentido literal de um enunciado. A própria ideia de literalidade é questionável e se apresenta mais como uma noção metafórica ligada à representação 
de uma imagem da letra que apreende o sentido em uma expressão linguística do que uma verdadeira relação objetiva entre res e verba, ou entre coisa e palavra, ou ainda entre significado e significante.

Mesmo que fosse possível dizer o que se entende por literalidade, vimos também que a busca por um sentido literal dos conceitos jurídicos não só é vã como impertinente, dado que é o poder criativo e imagético do arsenal linguístico figurado do direito que propicia o trabalho dogmático. 0 foco de atenção do jurista, pois, em relação a sua linguagem, deve ser a rede de interações entre suas metáforas conceituais.

Se as teorias positivistas privilegiavam o caráter semântico da linguagem jurídica e davam pouca importância aos aspectos performativos do discurso jurídico, as teorias retóricas do direito subvertem essa ordem e colocam a semântica em função da pragmática. Do ponto de vista retórico, a própria pragmática se submete à retórica e, consequentemente, aos efeitos da persuasão. Para o teórico retórico é importante observar, analisar e compreender como o jurista manipula o conjunto das metáforas conceituais do direito. Isto é, torna-se imprescindível para o retórico entender como funciona o processo criativo de imaginação científica no desenvolvimento dos conceitos jurídicos.

\section{Notas}

1 "Metaphor has by now been defined in so many ways that there is no human expression, whether in language or any other medium, that would not be metaphoric in someone's definition. This could mean that the word has become useless and that we should all take up some other line of inquiry. Surely when a word can mean everything it risks meaning nothing. But the interesting thing is that in spite of differences in the scope of our definitions, we all meet everyday certain statements that everyone recognizes as metaphor and calls by that name".

2 „Mag der Trieb zur Geselligkeit in den einzelnen Menschen auch noch so stark sein, erst die eiserne Klammer des Staates zwängt die größeren Massen so aneinander, daßjetztjene chemische Scheidung der Gesellschaft, mit ihrem neuen pyramidalen Aufbau, vor sich gehen muß. (...) Die Gewalt giebt das erste Recht, und es giebt kein Recht, das nicht in seinem Fundamente Anmaßung Usurpation Gewaltthat ist".

3 „Der Magie des werdenden Staates".

4 "Die eiserne Klammer, die den Gesellschaftsprozeß erzwingt".

5 „Ein Nervenreiz zuerst übertragen in ein Bild! erste Metapher. Das Bild wieder nachgeformt in einem Laut! Zweite Metapher. Und jedesmal vollständiges Ueberspringen der Sphäre, mitten hinein in eine ganz andere und neue".

6 "Literal or original language is merely a metaphor or figure that has repressed the ways in which it produces, rather than names, the stability of concepts".

7 „Jeder Begriff entsteht durch Gleichsetzen des Nicht-Gleichen. So gewiss nie ein Blatt einem anderen ganz gleich ist, so gewiss ist der Begriff Blatt durch beliebiges Fallenlassen dieser individuellen 
Verschiedenheiten, durch ein Vergessen des Unterscheidenden gebildet und erweckt nun die Vorsetullung, als ob es in der Natur ausser der Blättern etwas gäbe, das „Blatt“ wäre, etwa eine Urform, nach der alle Blätter gewebt, gezeichnet, abgezirkelt, gefärbt, gekräuselt, bemalt wären, aber von ungeschickten Händen, so dass kein Exemplar correkt und zuverlässig als treues Abbild der Urform ausgefallen wäre".

8 "The elimination of ambiguity and 'useless' language, or the commitment to complete literalism is both absurdly impossible and contradictory. (...) The desire of a pure literal language, a language devoid of ambiguity or figures, produces a chaos of things, an outrageous and insecure collection of signifiers with no coherent sense".

9 "(...) speak of things as they are."

10 "(...) all the artificial and figurative application of words."

11 "(...) powerful instrument of error and deceit".

12 "(...) love to deceive, and be deceived."

13 “(...) buon senso illuministico."

14 "I have given a faithful history of my travels for sixteen years and above seven months; wherein I have not been so studious of ornament as truth. I could perhaps like others have astonished thee with strange improbable tales; but I rather chose to relate plain matter of fact in the simplest manner and style; because my principal design was to inform, and not to amuse thee".

15 A analogia é inspirada na análise feita por Umberto Eco de uma passagem do romance de Manzoni, I promessi sposi, em que dois iletrados procuram se corresponder por meio de carta. A ironia típica do romantismo do século XIX é um recurso fundamental que se apresenta em vários momentos da obra de Manzoni.

16 “(...) metaphorical assertion can remain true even though it turns out that the statement of similarity on which the inference to the metaphorical meaning is based is false".

17 "We argue that no strict dichotomy exists between literal or scientific language on the one hand and metaphorical language on the other. We do not use 'metaphor' as a pejorative term. Rather, whenever we use language, there is a richness of association that goes beyond any restricted notion of what we might call 'literal' meaning. (...) we wish to see the literal sense as the limit of a continuum of metaphor rather than as a sharply distinct form of meaning from which metaphor is to be defined as a deviation. In particular, we suggest that much of our understanding of language rests on our being within a holistic symbol system, encoded in the schemas in our heads, many of which have been assimilated unconsciously. Our use of language rests not on precise definitions but on the (not necessarily conscious) use of schemas that have resulted from rich, complex, and by no means unambiguous interaction with a physical and social reality".

\section{Referências}

ADEODATO, João Maurício. Filosofia do direito. Uma crítica à verdade na ética e na ciência. São Paulo: Saraiva, 1996.

ARISTÓTELES. Retorica. Trad. Marco Dorati. Milano: Mondadori, 1996.

BLACK, Max. More about metaphor. In: ORTONY, Andrew. Metaphor and thought. Cambridge: Cambridge University Press, 1993, pp. 19-41.

B00TH, Wayne C. Metaphor as rhetoric: the problem of evaluation. In: SACKS, Sheldon (Ed.). On metaphor. Chicago/London: The University of Chicago Press, pp. 47-70, 1979. 
CASERTANO, Giovanni. Paradigmas da verdade em Platão. Trad. M. da G. G. de Pina. São Paulo: Loyola, 2010.

COLEBROOK, Claire. Irony. London and New York: Routledge, 2006.

DE MAN, Paul. The epistemology of metaphor. In: SACKS, Sheldon. On metaphor. Chicago/London: The University of Chicago Press, 1978, pp. 11-28.

ECO, Umberto. Tra menzogna e ironia. Milano: Bompiani, 1998.

FINGER, Ingrid. Metáfora e significação. Porto Alegre: EDIPUCRS, 1996.

GIBBS Jr., Raymond W. The poetics of mind. Figurative thought, language, and understanding. Cambridge: Cambridge University Press, 2002.

LAKOFF, George. Contemporary theory of metaphor. In: ORTONY, Andrew. Metaphor and thought. Cambridge: Cambridge University Press, 1993, pp. 202-251.

LARENZ, Karl. Metodologia da ciência do direito. Trad. J. Lamego. Lisboa: Calouste Gulbenkian, 1997.

LOCKE, John. An essay concerning human understanding. Indianapolis: Hackett, 1996.

MÜLLER, Friedrich. Teoria estruturante do direito. v. I. Trad. P. Naumann; E. A. de Souza. São Paulo: Revista dos Tribunais, 2009.

NIETZSCHE, Friedrich Wilhelm. Fünf Vorreden. Der griechische Staat. In: NIETZSCHE, Friedrich Wilhelm. Nachgelassene Schriften 1870-1873. In: COLLI, Giorgio; MONTANARI, Mazzino (Hrsg.). Friedrich Nietzsche, Kritische Studienausgabe - in fünfzehn Bände, Bd. I, Berlin: Walter de Gruyter, 1988a.

Über Wahrheit und Lüge im aussermoralischen Sinne. In: NIETZSCHE, Friedrich Wilhelm. Nachgelassene Schriften 1870-1873. In: COLLI, Giorgio; MONTANARI, Mazzino (Hrsg.). Friedrich Nietzsche, Kritische Studienausgabe - in fünfzehn Bände, Bd. I, Berlin: Walter de Gruyter, 1988b.

PALMA, Héctor A. Metáforas en la evolución de las ciencias. Buenos Aires: Jorge Baudino Ediciones, 2004. 
PARINI, Pedro. A noção de direito entre conceito e metáfora.Prim@ Facie. Vol. 13, n. 24, João Pessoa: UFPB, 2014a, pp. 1-37.

Ironia e metáfora na filosofia do direito. Pragmatismo jurídico. Fundamentos e métodos de uma doutrina interdisciplinar. Recife: UFPE, 2014b, v. 1, p. 621-652.

PLATÃO. 0 banquete - Apologia de Sócrates. Trad. C. A. Nunes. Belém: EDUFPA, 2001.

ROSS, Alf. Tû-tû. Trad. E. Bini. São Paulo: Quartier Latin, 2004.

RUMELHART, David E. Some problems with the notion of literal meanings. In: ORTONY, Andrew. Metaphor and thought. Cambridge: Cambridge University Press, 1993, pp. 71-82.

SCHLIEFFEN, Katharina (SOBOTA) von. Rhetorische Analyse des Rechts. Risiken, Gewinn und neue Einsichten. In: SONDRY, Rouven. Eine interdisziplinäre Einführung in die rhetorische Praxis. Heidelberg: C.F. Müller Verlag, 2006, pp. 24-64.

SEARLE, John. R. Metaphor. In: ORTONY, Andrew. Metaphor and thought. Cambridge: Cambridge University Press, 1993, pp. 83-111.

Recebido em: 24-11-2015

Aprovado em: 15-12-2015

\section{Pedro Parini}

Professor Adjunto no Curso de Direito da Universidade Federal da Paraíba (UFPB). Docente do Programa de Pós-Graduação em Ciências Jurídicas da UFPB. Coordenador do Grupo de Pesquisa \&quot; Retórica, Hermêneutica e Direito\&quot; vinculado à UFPB. Pós-doutorado pela Università di Bologna, Itália com duração de 12 meses e financiamento pela CAPES. Doutor em Direito pela Universidade Federal de Pernambuco (UFPE).

E-mail:pparini@gmail.com

Universidade Federal da Paraíba. Centro de Ciências Jurídicas.

Campus Universitário I. Cidade Universitária 58059900 - João Pessoa - PB. Brasil 